\title{
Soybeans Processing for Biodiesel Production
}

\author{
A. Bulent Koc, Mudhafer Abdullah and Mohammad Fereidouni \\ University of Missouri \\ United States
}

\section{Introduction}

There is a need for alternative energy sources to petroleum-based fuels due to the depletion of the world's petroleum reserves, global warming and environmental concerns. Biodiesel is a clean and renewable fuel which is considered to be the best substitution for diesel fuel (Singh \& Singh, 2010). Soybean oil is one of the major feedstocks for biodiesel production. According to United States Department of Agriculture (USDA), the U.S. was the largest producer of soybean oil in the world in 2006/2007. The U.S. was followed by Argentina, China, Brazil and India in soybean oil production. The U.S. produced $34.5 \%$ of total soybean oil in the world (United States Department of Agriculture, 2008). This amount of oil is a promising source for biodiesel production from a natural and environmentally friendly agricultural product (Patil \& Deng, 2009). Although Food and Agriculture Organization of the United Nation (FAO) stated many environmental problems associated with large scale production of soybeans and maize (FAO, 2009), Life Cycle Assessment (LCA) studies indicated that cultivation of soybeans has less negative impacts on environment than some other oil seeds like sunflower and rapeseed (Sanz Requena et al., 2010).

In addition to biodiesel production, soybeans can be used to produce ethanol. Soybean hulls contain significant amount of carbohydrate for ethanol production and producers prefer to use soybean hulls for animal feeding because of its high protein content (Mielenz et al., 2009). Although, biodiesel is usually used as a blend with petro-diesel at varying ratios, it can also be used to fuel compression ignition engines alone. The results of engine emission tests showed that use of biodiesel alone produced less emissions of CO, HC, NOx and smoke than petro-diesel (Qi et al., 2009). Conventional biodiesel production from soybeans uses separate processes for oil extraction and biodiesel conversion. Oil extraction from soybeans is accomplished by using mechanical presses, solvent extraction, supercritical fluid extraction and microwave- and ultrasound-assisted solvent extractions. The extracted oil is degummed and converted to biodiesel via transesterification. Transesterification is a chemical reaction process during which the oil is combined with alcohol, usually ethanol or methanol, in the presence of a catalyst to form fatty esters and glycerol. Reducing biodiesel production costs from $\$ 3.11$ per gallon to below the petro-diesel cost of $\$ 3.0$ per gallon is important to make biodiesel competitive in the diesel fuel market (Kargbo, 2010).

The objective of this chapter is to provide a literature review on oil extraction and biodiesel production from soybeans and to discuss the uses of high intensity ultrasound in processing 
of soybeans for biodiesel production. Three examples of ultrasound applications in soybean processing for biodiesel production will be discussed. The first example will investigate the effects of solvent amount, oil extraction time and ultrasonication on soybean oil yield. The second example will examine the ultrasound-assisted transesterification of soybean oil for biodiesel production. The third application will investigate the feasibility of integrating soybean oil extraction and biodiesel production processes using ultrasound-assisted in-situ transesterification.

\section{Literature review}

Extracting oil from soybeans requires pretreatment of the grains. Pretreatment includes operations of cleaning and drying, dehulling and grinding (Fig. 1). Use of mechanical presses, solvent extraction, supercritical fluid extraction and microwave-and ultrasoundassisted oil extraction are the major processes practiced for oil extraction from soybeans.

\section{Mechanical Extraction}

Mechanical pressing of oil seeds is one of the most common methods of oil extraction in the world. However, single screw mechanical presses leave about $8-14 \%$ of the available oil in the oil seeds (Singh \& Bargale, 2000). In mechanical extraction, effects of enzymes are neutralized by heating (Gerpen et al., 2002). An efficient way of providing heat for enzyme neutralization is using an extruder. Extruders provide enough pressure and temperature on seeds to deactivate enzymes (Gerpen et al., 2002). Jung and Mahfuz (2009) used a dry extruder with high temperature for extraction of oil and protein. They found that increased extruder pressure increased the protein solubility in soybean oil.

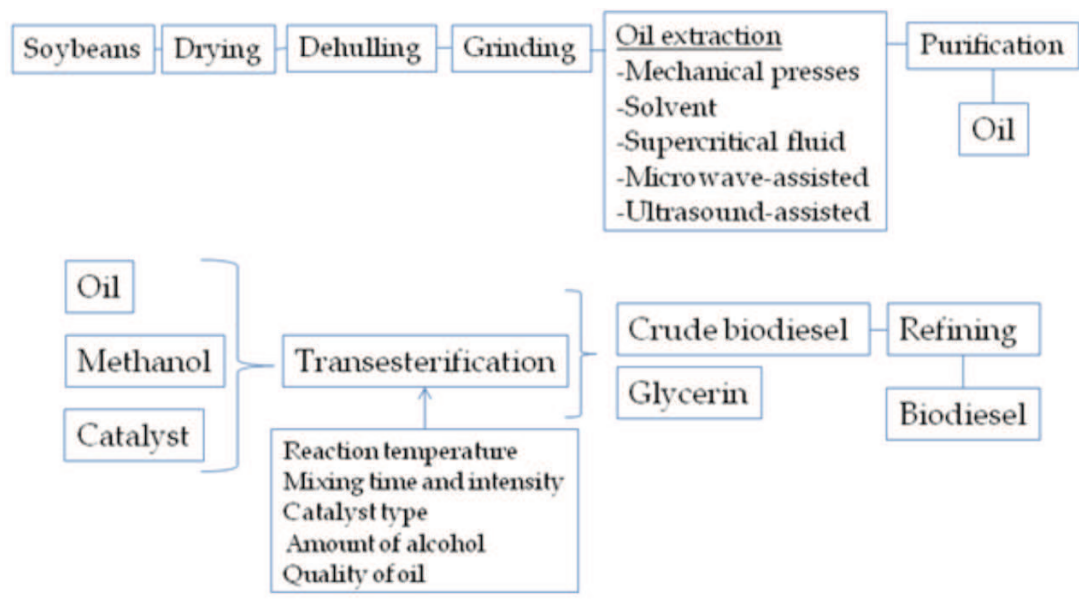

Fig. 1. Soybean processing for oil extraction and biodiesel production.

\section{Solvent Extraction}

Hexane is extensively used for oil extraction from soybeans and other oilseeds because of its low vaporization temperature, high stability, low corrosiveness and low greasy residual effects (Seth et al., 2007). Johnson and Lucas (1983) proposed to use other non-petroleum 
materials instead of hexane as a solvent. They mentioned a set of problems with hexane such as the price which is dependent on fossil fuels market and its negative environmental effects (Gandhi et al., 2003). Russin et al. (2010) stated that more than 70 different solvents could be used for oil extraction from soybeans. However, the focus in many of the recent studies were mainly on using various alcohols on oil extraction (Russin et al., 2010). Seth et al. (2007) showed that the use of isopropyl alcohol caused higher extraction rates and oil recovery than hexane (Seth et al., 2007). Lou et al. (2010) compared Chilean chickpea oils extracted with hexane, isopropanol and a mixture of hexane and isopropanol in a ratio of 3:2. Mixture of hexane and isopropanol showed higher extraction rates than hexane and isopropanol alone.

\section{Supercritical Fluid Extraction}

Supercritical carbon dioxide utilized as a relatively new technique to extract oil and isoflavones from soybeans (Mendes et al., 2002). Zaidul et al. (2007) used supercritical carbon dioxide $\left(\mathrm{SC}-\mathrm{CO}_{2}\right)$ for extraction of oil from palm kernel (Zaidul et al., 2007). Salgin (2007) used supercritical $\mathrm{CO}_{2}$ and supercritical ethanol mixture for oil extraction from jojoba oilseeds. Their results showed an improvement on oil extraction rate. Temperature and pressure had the main effects on supercritical fluid extraction (SalgIn, 2007). Kao et al. (2008) compared solvent extraction with supercritical carbon dioxide extraction and reported that supercritical carbon dioxide extraction provided higher oil yields than solvent extraction (Kao et al., 2008).

\section{Ultrasound-assisted Extraction}

Luthria et al. (2007) compared several techniques for oil extraction from soybeans. They obtained $93.3 \%$ oil yield with ultrasonication technique, which was the highest amount in comparison with other methods (Luthria et al., 2007). The ultrasound and microwave techniques used separately and in combination by Cravotto et al. (2008) for extracting oil from soybeans and micro-algae. Ultrasound/microwave extraction techniques reduced the extraction time and solvent amounts and produced higher extraction efficiency with less environmental impact than conventional (Soxhlet) extraction (Cravotto et al., 2008). Zhang et al. (2008) used both ultrasonic and conventional methods for oil extraction from flaxseed and stated that ultrasound is more efficient than the conventional method for oil extraction from flaxseed (Zhang et al., 2008). Ultrasonication method used to extract oil from Chilean chickpea by Lou et al. (2010). They indicated that use of ultrasound increased the speed of extraction and the final product quantity (Lou et al., 2010).

\section{Microwave-assisted Extraction}

Uquiche et al. (2008) investigated the oil extraction and oil quality from Chilean hazelnut. They used microwave technique in pretreatment step and followed by mechanical pressing. Their result showed that microwave application improved both the oil quality and quantity (Uquiche et al., 2008). Enzymatic hydrolysis was another method, which was proposed by Kashyap et al. (2009) to increase oil extraction from soybeans. This method was applied after pretreatment and the results showed that enzymatic hydrolysis had significant effects on oil extraction from soybean flakes (Kashyap et al., 2007). Terigar et al. (2010) compared microwaves-assisted solvent extraction with conventional solvent process on extraction of isoflavones from soybeans. They reported that oil and isoflavones yields increased by 
continuous microwave system in comparison with solvent extraction method (Terigar et al., 2010).

\section{Refining Oil}

Degumming is the first step in the oil refining processes and the goal is to remove the phospholipids present in the oil by adding hydrating agents. Water and acid degumming are two main methods which were applied by the oil industries (Ribeiro et al., 2008). Pagliero et al. (2007) used membrane separation as an alternative process for oil degumming. They mentioned that membrane separation is a potential process compared to conventional degumming processes (Pagliero et al., 2007).

\section{Biodiesel production}

\section{Transesterification method}

Transesterification is a common method for biodiesel production from vegetable oils and animal fats and usually preferred instead of direct esterification (Abreu et al., 2003). In transesterification or alcoholysis, fats or oils react with alcohol in presence of a catalyst to form alky esters and glycerol (Meher et al., 2006). The transesterification process reduce the viscosity of oils which is higher than petro-diesel (Stavarache et al., 2005). Selecting a suitable alcohol and catalyst is important for transesterification method. Various alcohols such as methanol, butanol, ethanol, propanol and amyl alcohol can be used for transesterification. Methanol is used widely because it is relatively cheaper than other alcohols and has chemical and physical advantages over other alcohols (Ma \& Hanna, 1999). In theory 3 moles of alcohols are required to neutralize 1 mole of triglyceride to produce 3 moles of fatty acid methyl ester (FAME) and 1 mole of glycerin (Leung et al., 2010). A good catalyst is also needed to obtain a reasonable rate for transesterification of triglycerides and its conversion to biodiesel (Lotero et al., 2005). Acid and alkaline catalysts can be used in the form of homogeneous or heterogeneous catalysts for transesterification process (Pereira et al., 2007). Research and industry prefer alkali catalysts, such as $\mathrm{NaOH}$ and $\mathrm{KOH}$ because alkali catalysts react faster and are less corrosive than acidic compounds (Pinto et al., 2005). High water and free fatty acid in oil reduce the effectiveness of catalysts, produce soap and require considerable amounts of catalysts. Free fatty acids (FFAs) and water in oil needs to be removed before applying base catalysis process. Marchetti et al. (2008) used acid catalyst which eliminated the above-mentioned problems. They stated that acid catalysts act better than base catalysts, because acid catalysts are able to convert higher percentage of free fatty acids (FFAs) to triglyceride. The first choice for acid catalysts is sulfuric acid which was used by several researchers (Marchetti \& Errazu, 2008). In addition to the acid and base catalysts, enzyme catalysts are also considered for biodiesel production. The enzyme catalysts are gaining more interest in recent years because they don't constitute soap and their process is simple to complete. Enzymatic catalysts are currently not feasible for commercial productions since they have higher cost and need longer reaction time (Leung et al., 2010).

\section{Ultrasound-assisted transesterification}

Ultrasound technology was employed in various stages of biodiesel production. Stavarache et al. (2005) used low frequency ultrasound energy for biodiesel production and compared the results with conventional biodiesel production processes. They used three different 
types of alcohols and $\mathrm{NaOH}$ as a catalyst. They showed that ultrasonication had a positive effect on transesterification process and reduced the process time and saved energy in the biodiesel production (Stavarache et al., 2005). Santos et al. (2009) studied the effect of ultrasonication during the process of biodiesel production from soybean oil. They used methanol and $\mathrm{KOH}$ as a catalyst. They showed the positive effect of ultrasound on biodiesel yield enhancement (Santos et al., 2009). Cintas et al. (2010) used high power ultrasound in a continuous system for biodiesel production from soybeans. They used ultrasound after heating the oil and premixing with a mechanical stirrer. Their results showed considerable improvement on saving time and energy (Cintas et al., 2010). Koc and McKenzie (2010) studied the effect of ultrasonication on glycerol separation during transesterification of soybean oil and optimized this process using response surfaces methodology (Koc \& McKenzie, 2010). Yu et al. (2010) also mentioned that ultrasonication improved biodiesel production. They used ultrasound waves to produced biodiesel from soybean oil (Yu et al., 2010). Li et al. (2004) studied the effect of ultrasound duration on oil extraction from soybeans and compared the results with conventional extraction method. The results showed a considerable improvement on both quantity and quality of the final product. Their result showed that ultrasound was able to reduce the amount of free fatty acids (Li et al., 2004). Chand et al. (2010) compared the biodiesel production of soybean oil by mechanical stirring and ultrasonication. They showed that, required time for biodiesel production reduced by the use of ultrasonication (Chand et al., 2010).

\section{In-situ Transesterification method}

In-situ transesterification is one of the methods which have some advantages over direct transesterification. Compared to conventional transesterification, in-situ transesterification is faster and both oil extraction and biodiesel conversion take place in a single step. In this method, oil containing materials contact with acid or alkali alcohol directly (Fukuda et al., 2001). In-situ transesterification eliminates the costly hexane extraction process and reduces the long production system associated with pre-extracted oil and finally maximizes alkyl ester yield (Verziu et al., 2009). In-situ transesterification could be improved by increasing the alcohol volume and process temperature (Ehimen et al., 2010). Georgogianni et al. (2008) used in-situ transesterification with alkali catalyst and methanol and compared it to conventional transesterification. Their results indicated that the process was faster and completed in about 20 minutes (Georgogianni et al., 2008). Similar results for the same method and materials were reported by Siatis et al. (2006). Harrington and D'Arcy-Evans (1985) and Kildiran et al. (1996) tested in-situ transesterification with acid catalysts and methanol. Their results showed increase in total oil production. Quian et al. (2008) investigated the quality of biodiesel production from cotton seeds by in-situ transesterification in presence of a base catalyst. They showed that molar ratio of alcohol to cottonseed oil is important for biodiesel production (Qian et al., 2008). Similar results were reported by Santos et al. (2009). The highest biodiesel yield was accomplished when 9:1 alcohol to oil ratio was used (Santos et al., 2009). In a recent study, Shiu et al. (2010) used two-step in-situ transesterification with acid catalyst treatment followed by a base catalyst to produce biodiesel from rice bran. They successfully produced high amount of biodiesel in two-step in-situ transesterification in comparison to one step in-situ transesterification (Shiu et al., 2010). 


\section{Materials and methods}

Response surfaces methodology was used to design a set of experiments to determine the effects of ultrasonication on oil extraction from soybeans. Ultrasound effect on soybean oil transesterification and in-situ transesterification were also investigated.

\section{Materials}

Soybeans (Glycine max L.5N416) was obtained from University of Missouri, Bradford Research and Extension Center (Columbia, MO). Analytical grade hexane was purchased from Chemstore (Columbia, MO) and used as a solvent. An electric grinder (Black and Decker®, Burr Mill CBM210, U.S.A.) was used at its fine grind setting to grind the dried soybeans. The particle size distribution of the ground seeds was determined by using a sieve analyzer (Sieve Tester SS-15, GILSON, INC, U.S.A.). An electric oven (Fisher scientific Isotemp ${ }^{\circledR}$ Model $630 \mathrm{~F}$ ) was used to measure the moisture content. The high intensity ultrasound system used for this study was a $1000 \mathrm{~W}$ ultrasound processor with frequency of $20 \mathrm{kHz}$ (UIP 1000, Hielscher, Germany).

\section{Methods}

Eight pounds of soybeans were soaked in warm water and dehulled manually. The dehulled soybeans were oven-dried for 24 hours and the moisture content was determined. The dried soybeans were ground and particle size distribution was determined by using a sieve analyzer. The total oil content of soybeans was determined by Soxhlet extraction. Ten grams of ground seeds placed in an extraction thimble and $150 \mathrm{ml}$ hexane was refluxed using a Soxhlet extractor. The temperature of the hexane was maintained at $70{ }^{\circ} \mathrm{C}$ and the extraction continued for 10 hours. The total oil content was determined by calculating the difference between the dry weight of the ground seeds before and after Soxhlet extraction.

\section{Design of experiments and statistical analysis}

The response surfaces methodology consists of a group of empirical techniques devoted to the evaluation of relationships existing between a cluster of controlled experiment factors and measured responses according to one or more selected criteria (Fereidouni et al., 2009). ECHIP experimental design software (Wilmington, DE) was used to design the experiments and analyze the results of oil extraction stage. To design the experiments, three different factors of particle size, solvent amount and ultrasonication power were selected. The design composed of 19 experimental trials with 5 replications. Five replicate runs were performed to allow the estimation of pure error. All experiments were carried out in a random order to minimize the effect of unexplained variability in the observed responses due to irrelevant factors (Sin et al., 2006). Table 2. shows the independent variables and their levels used in the experimental design. The statistical analyses of direct biodiesel production and in-situ transesterification stages were carried out by measuring the standard deviation for all the results and replicating the trials twice.

\begin{tabular}{cccc}
\hline & Particle size $(\mathrm{mm})$ & Ultrasound power $(\%)$ & Solvent amount $(\mathrm{ml})$ \\
\hline-1 & 0.250 & 50 & 100 \\
0 & 0.500 & 70 & 150 \\
+1 & 1.00 & 90 & 200 \\
\hline
\end{tabular}

Table 1. Independent variables and their levels used in Central Composite Design (CCD). 


\section{Environmental Scanning Electron Microscope (ESEM) Images}

The surface images of soybeans after grinding, before and after oil extraction with ultrasound and direct solvent extraction were captured using environmental scanning electron microscopy (ESEM, FEI Quanta 600 FE SEM, FEI Company, OR, USA).

\section{Yield measurement}

Hexane-oil mixtures were collected after ultrasonication. The samples were centrifuged at $1000 \mathrm{rpm}$ for $20 \mathrm{~min}$ to separate the fine solid particles that may still be present in the sample. After centrifugation, $1 \mathrm{ml}$ of supernatant was collected from the sample and weighed using a precision scale. Hexane was evaporated by placing the samples in an oven at $105{ }^{\circ} \mathrm{C}$ for 2 hours. The initial and final weight of the samples were measured and recorded. The oil yield ( $Y$ ) was determined by using the following formula (Equation 1 ).

$$
Y=\frac{w_{e}}{w_{t}} \times 100
$$

Where $w_{e}$ is the weight of the extracted oil $(g)$ and $w_{t}$ is the weight of the total oil in each sample $(g)$. The total oil content $\left(w_{t}\right)$ of the soybeans was determined by using the Soxhlet extraction.

\section{Conventional biodiesel production}

Refined soybean oil was purchased from a local store. In the first step, the amount of required $\mathrm{KOH}$ was determined by titration. The titration amount for this study was determined to be $5.18 \mathrm{~g} \mathrm{KOH} /$ liter oil. $\mathrm{KOH}$ (>92\% purity) in the amount of $0.259 \mathrm{~g}$ was dissolved in $50 \mathrm{ml}$ of methanol (>95\% purity) and the mixture was heated to $50{ }^{\circ} \mathrm{C}$ before mixing it with the oil. The methanol-KOH solution was added to soybean oil at $50{ }^{\circ} \mathrm{C}$ with a volumetric ratio of 1:5. The mixture was blended by using ultrasound at a power level of $70 \%$ or using a mixer at $700 \mathrm{rpm}$ for 5 minutes. The reaction components left to settle for 24 $\mathrm{h}$ at room temperature to separate glycerin from crude biodiesel. After settling, washing phase was carried out by adding $30 \%(\mathrm{v} / \mathrm{v})$ of warm water at $50{ }^{\circ} \mathrm{C}$ to the crude biodiesel and stirring for $5 \mathrm{~min}$. The water-crude biodiesel mixture was left to settle for $24 \mathrm{~h}$ to separate soap layer from biodiesel phase. Washing process was repeated for three times to make sure that all the soap was removed from biodiesel. The washed biodiesel was then placed in an oven at $70{ }^{\circ} \mathrm{C}$ for $6 \mathrm{~h}$ to evaporate any water that might be present during washing.

\section{Biodiesel production with ultrasound-assisted in-situ transesterification}

The in-situ transesterification procedure was carried out using $30 \mathrm{~g}$ of dried soybeans $(4.5 \% \mathrm{wb})$ for each trial. Fine grinding was applied to soybeans to get an average particle size of $0.25 \mathrm{~mm}$. The reaction was conducted by using methanol (>95\% purity) to oil molar ratio of 6:1. The amount of $\mathrm{KOH}$ was determined by titration and $0.03 \mathrm{~g}$ of solid $\mathrm{KOH}(92 \%$ purity) was dissolved in methanol. Three levels of methanol to oil volumetric ratios (15:1, 20:1 and 25:1) were used in the experimental design. The KOH-methanol mixture was added to ground soybeans and ultrasonication power was applied at two levels (70 and $90 \%$ ) for $30 \mathrm{~min}$. After ultrasonication, the mixture was left to settle for $2 \mathrm{~h}$ and the liquid phase (methanol with crude FAME) was separated and centrifuged at $1000 \mathrm{rpm}$ for $10 \mathrm{~min}$. The spent soybean flakes were washed by using methanol at 2:1 v/w ratio. The mixture of methanol and soybean flakes was left to settle for $2 \mathrm{~h}$. The liquid phase was separated from 
the solids and centrifuged at $1000 \mathrm{rpm}$ for $10 \mathrm{~min}$ to remove the solids. Hexane was used to separate the fatty acid methyl ester from the excess methanol which was used for washing. Hexane was used at a volumetric ratio of $1: 1$. Water was added to the mixture at volumetric ratio of 3:1. The mixture was heated to $50{ }^{\circ} \mathrm{C}$ while stirring for $20 \mathrm{~min}$. Next, the mixture was left to settle at room temperature for $24 \mathrm{~h}$. The upper phase (hexane and biodiesel) was separated from methanol and washed with water at the same volumetric ratio to neutralize crude biodiesel. Sodium sulfate was used to dry water in FAME phase. Finally, hexane was evaporated at $70{ }^{\circ} \mathrm{C}$ for $6 \mathrm{~h}$, and the FAME content was analyzed by GC. The spent soybean flakes were dried for $24 \mathrm{~h}$ at $104{ }^{\circ} \mathrm{C}$ and Soxhlet oil extraction process was used for $8 \mathrm{~h}$ by refluxing $120 \mathrm{ml}$ of hexane through the spent soybean flakes to determine the amount of oil left in soybean flakes.

\section{Properties of soybean oil biodiesel}

The properties of biodiesel were analyzed at MFA Oil Laboratory (Columbia, Missouri). The measured properties included cloud point, flash point, sulfur content, water content, distillation, acid number, density and viscosity. A Varian 3400 equipped with Varian 8200 auto sampler and a FID detector was used to determine the fatty acid composition of the crude biodiesel. A $30 \mathrm{~m} \times 0.25 \mathrm{~mm}$ DB-WAXeter fused silica column (Agilent Technologies) was used for the measurement. Oil samples were quantitatively weighed in a volumetric flask to prepare a solution of approximately 5-6 mg of hexane. A known aliquot containing approximately $4-5 \mathrm{mg}$ of sample was pipetted to a reaction vial. One milliliter of internal standard (C17:0 methyl ester) was added to hexane and mixed well. The hexane was then evaporated to dryness using a stream of nitrogen. Two $\mathrm{ml}$ of BF3/Methanol reagent (Supelco) was added, mixed and the reaction vial was capped tightly. The reaction mixture was heated to $100^{\circ} \mathrm{C}$ and maintained at that temperature for 30 min with occasional shaking. Then, the mixture was cooled and $1 \mathrm{ml}$ of deionized water was added. The methyl esters of fatty acids were extracted with $2 \mathrm{ml}$ of hexane. The extract was dried with anhydrous sodium sulfate and $3 \mathrm{ml}$ of extract was injected into Gas Chromatograph. Quantitative analysis was carried out using standard fatty acid methyl esters and C17:0 (Methyl ester) as internal standard. The results of the analysis were represented in terms of the percentage of fatty acid in the oil samples. Helium, at a rate of $1 \mathrm{ml} / \mathrm{min}$, was used as a carrier gas, the injector temperature was set at $250{ }^{\circ} \mathrm{C}$ and the column temperature was programmed to increase the temperature starting from $170^{\circ} \mathrm{C}$ at a rate of $1{ }^{\circ} \mathrm{C} / \mathrm{min}$.

\section{Results and discussions}

\section{Results of ultrasound-assisted oil extraction from soybeans}

The fitting of the model was investigated by analyzing the coefficients of variables and the corresponding coefficient of determination values $\left(R^{2}\right)$ (Table 2). Coefficient of determination is defined as the ratio of the explained variation to the total variation and is a measure of the degree of fit (Nur 'Aliaa et al., 2010). It is also the proportion of the variability in the response variables, which is accounted by the regression analysis. When $R^{2}$ approaches unity, the empirical model fits the actual data better (Sin et al., 2006). Joglekar and May (1987) stated that $R^{2}$ should be at least 0.80 for a good fit of a model. The $R^{2}$ value for the response variable was higher than 0.80 indicating that the regression models explained the control choices which had significant effects on reaction performance. The probability $(p)$ value of regression model was greater than 0.001 which showed no lack-of-fit. 


\begin{tabular}{cccc}
\hline Term & Coefficients & SD & $\boldsymbol{P}$ \\
\hline$X_{0}$ & 55.2109 & & \\
$X_{1}$ & 0.0182 & 0.171914 & -0.9180 \\
$X_{2}$ & 12.763 & 3.43828 & $0.0048^{* *}$ \\
$X_{3}$ & -0.34076 & 0.0687656 & $0.0008^{* *}$ \\
$X_{1} X_{2}$ & 0.165688 & 0.192206 & -0.4110 \\
$X_{1} X_{3}$ & -0.00390625 & 0.00384411 & -0.3361 \\
$X_{2} X_{3}$ & -0.034825 & 0.0768823 & -0.6613 \\
$X_{1}^{2}$ & 0.00752604 & 0.0164441 & -0.6580 \\
$X_{2}^{2}$ & 5.89541 & 6.57763 & -0.3934 \\
$X_{3}^{2}$ & 0.000804165 & 0.00263105 & -0.7668 \\
$R^{2}$ & 0.830 & & \\
Adjusted $R^{2}$ & 0.660 & & \\
$P$ or probability & 0.0136 & & \\
\hline
\end{tabular}

Table 2. Coefficients for response of oil yield (\%) depending on the control variables $\left(X_{0}\right.$ : constant, $X_{1}$ : ultrasound power, $X_{2}$ : average particle size, $X_{3}$ : hexane amount).

\section{Effect of hexane, ultrasonication and particle size on yield}

ANOVA results (Table 3) shows the mean of squares, degree of freedom and P-value for the final response (Oil yield).

\begin{tabular}{cccc}
\hline Source & Mean squares & DF & P-Value \\
\hline Ultrasound power & 13.0438 & 2 & 0.8967 \\
Average particle size & 861.954 & 2 & 0.0131 \\
Hexane amount & 1456.99 & 2 & 0.0026 \\
Ultrasound power vs. Particle size & 87.8475 & 1 & 0.4110 \\
Ultrasound power vs. Hexane & 122.07 & 1 & 0.3361 \\
Particle size vs. Hexane & 24.2556 & 1 & 0.6613 \\
\hline
\end{tabular}

Table 3. ANOVA for independent variables and their interactions.

According to ANOVA results, $p$-value is significant for particle size, hexane, power vs. particle size and power vs. hexane. But $p$-value is not significant for power and particle size vs. hexane. The results showed that the effect of particle size and hexane volume were highly significant on oil extraction, while ultrasound power did not show any significant effect. It was observed that the oil yield increased as the particle size was decreased. Qian et al. (2008) showed that the extraction rate of cottonseed oil increased with decreasing particle size of cottonseed flours. However, with further decrease in the particle size, the extraction of cottonseed oil was nearly constant. The optimum particle size for cottonseed was between 0.3 to $0.335 \mathrm{~mm}$ (Qian et al., 2008). A similar result was stated by Lim et al. (2010). They studied the effect of different particle size of Jatropha seeds on the oil yield. The results showed that the smaller particle size resulted more oil than larger particle size. According to Han et al. (2009), the main reason for increasing oil yield by decreasing the particle size is because of the increase in the specific surface area of oilseed interacting with the solvent.

The results showed that the hexane volume had a critical role on oil extraction although extraction by hexane was dependent on the particle size. The oil yield was increased with 
decrease in hexane volume from $200 \mathrm{ml}$ to $100 \mathrm{ml}$ when $70 \%$ ultrasound power was used (Fig. 2). Figure 3 shows the relationship between the particle size and ultrasound power and solvent to solid ratio of 15:1.

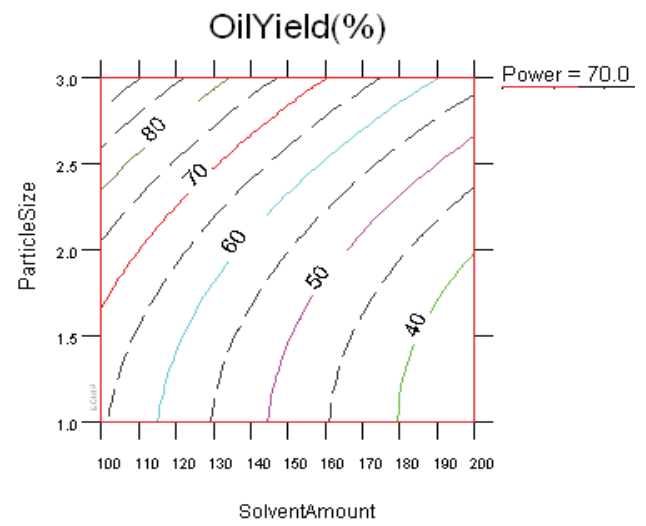

Fig. 2. Effect of particle size and solvent amount on oil yield.

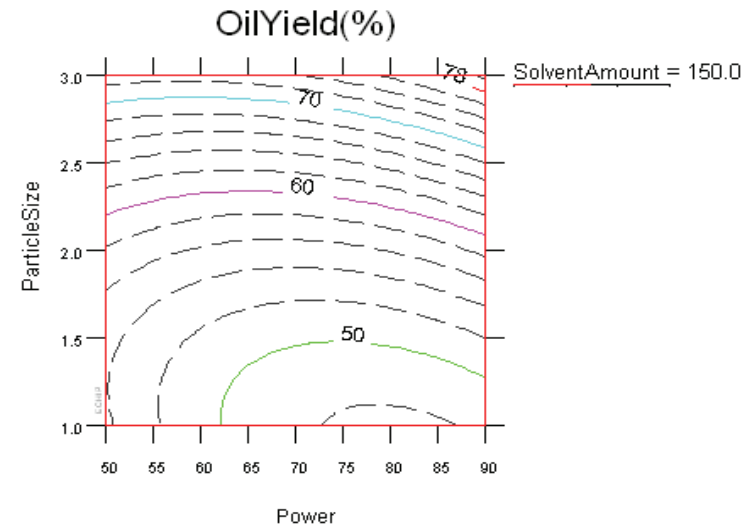

Fig. 3. Effect of particle size with ultrasound power on oil yield.

The solvent amount had significant effects on oil yield when ultrasound was applied. In the response surfaces trials, the lowest level of solvent to solid ratio was 10:1 and reducing the solvent to solid ratio increased the oil extraction rates. Additional experiments were conducted to determine the lowest solvent to solid ratio that can be used with ultrasonication. The three levels of solvent to solid ratio used in additional experiments were 4:1, 3:1 and 2:1 with ultrasonication of $30 \mathrm{~min}$. Each trial was replicated twice and the measured yield values were averaged. Fig. 4. shows the oil yield change with solvent to solid ratio. Reducing the solvent to solid ratio from 4:1 to 2:1 further increased the oil yield. 


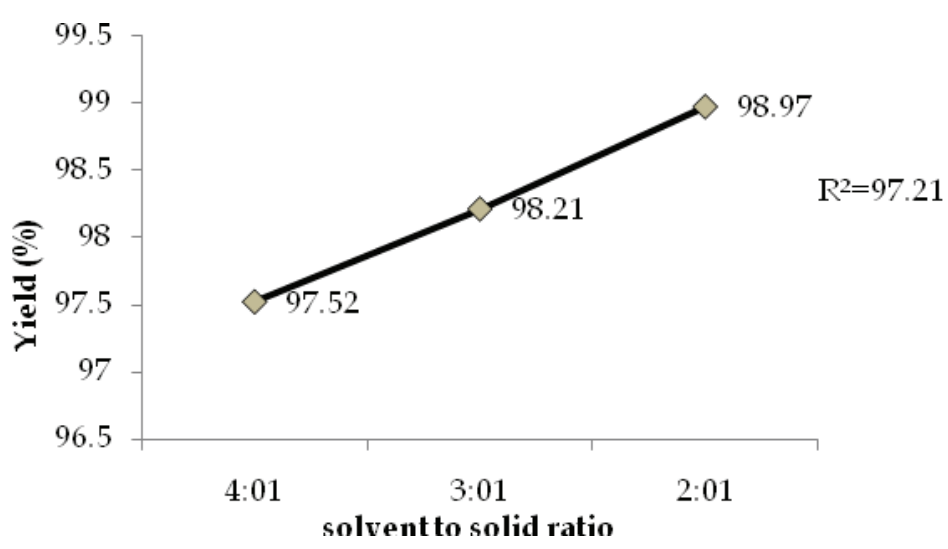

Fig. 4. Effect of solvent to solid ratio on oil extraction with ultrasonication.

\section{Environmental Scanning Electron Microscope (ESEM) Results}

Environmental Scanning Electron Microscope (ESEM) images for soybean flakes before and after extraction by Soxhlet and ultrasonication method are shown in Figures 5-7. The surface morphology of the soybeans was changed after oil extraction. Fig. 6. shows the changes on the soybean surface after $8 \mathrm{hr}$ of Soxhlet extraction. Fig. 7. shows the surface of the soybean flakes after $30 \mathrm{~min}$ of ultrasound-assisted oil extraction. The surface of the soybean flakes after Soxhlet extraction was brighter than the samples exposed to ultrasound-assisted oil extraction. This result was compatible with Li et al. (2004) who used electron microscopy images to monitor the effect of ultrasonication time on soybean flakes during oil extraction. They showed that the extended duration of ultrasonication could improve the oil yield (Li et al., 2004). The ESEM results also verified our results on soybean oil extraction rate by

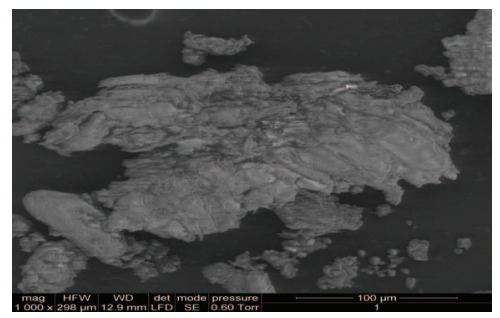

Fig. 5. Surface image of the soybean flakes before extraction.

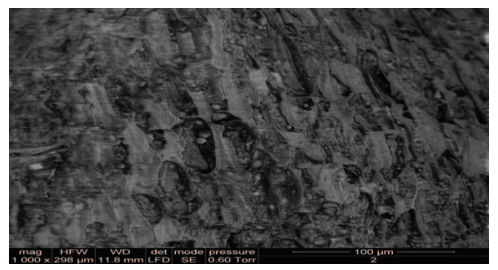

Fig. 6. Surface image of the soybean flakes after Soxhlet extraction. 


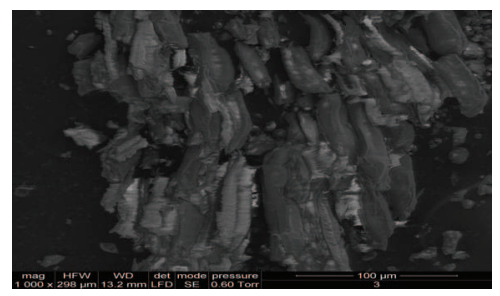

Fig. 7. Surface image of the soybean flakes after ultrasound-assisted oil extraction.

ultrasonication. As mentioned in previous section, the ultrasonication effect was not found significant on oil yield. The duration of ultrasonication might be the main reason for nonsignificant effect of ultrasound on the oil yield.

\section{Results of ultrasound-assisted biodiesel production from soybean oil}

Results of ultrasound-assisted transesterification process for biodiesel production from soybeans is shown in Table 4. The physical properties of biodiesel produced with ultrasound-assisted transesterification and mechanical stirring were within the ASTM standard range. High flash point of biodiesel produced by using ultrasonication $\left(170{ }^{\circ} \mathrm{C}\right)$ was higher than the biodiesel produced using mechanical stirring $\left(150^{\circ} \mathrm{C}\right)$. Sulfur content of both soybean oil biodiesel samples was lower than the maximum standard value. Water content of both samples were higher than standard range.

Ultrasonication produced higher biodiesel yield than the mechanical stirring. The standard deviation values between the ultrasound and mechanical stirring were significantly different for biodiesel viscosity, cloud point, flash point, water content and biodiesel yield at $p>0.05$ level.

\begin{tabular}{cccccc}
\hline Properties & Mechanical & Ultrasound & ASTM & SD & Method \\
\hline Density $(\mathrm{g} / \mathrm{ml})$ & 0.86 & 0.88 & $0.86-0.90$ & 0.01 & ASTM D 445 \\
Viscosity $\left({ }^{\circ} \mathrm{C}\right)$ & 4.66 & 6.06 & $1.9-6.00$ & 1.00 & ASTM D 445 \\
Cloud point $\left({ }^{\circ} \mathrm{C}\right)$ & -5.56 & -1.67 & & 2.75 & ASTM D 2500 \\
Flash point $\left({ }^{\circ} \mathrm{C}\right)$ & 150 & 172 & 130 & 15.55 & ASTM D 93 \\
Pour point $\left({ }^{\circ} \mathrm{C}\right)$ & -5.56 & -6.67 & & 0.55 & ASTM D 5853 \\
Sulfur content $(\mathrm{ppm})$ & 0.9 & 1.6 & 15 & 0.04 & ASTM D 5433 \\
Water content $(\mathrm{ppm})$ & 913.4 & 1650 & 500 & 520 & ASTM D 2709 \\
Acid value $(\mathrm{mg} \mathrm{KOH} / \mathrm{g})$ & 0.23 & 0.23 & \multirow{2}{*}{0.80} & 0.57 & ASTM D 664 \\
Biodiesel yield $(\%)$ & 94.5 & 95.5 & & & \\
\hline
\end{tabular}

Table 4. Properties of biodiesel produced using ultrasound and mechanical mixing.

\section{Results of ultrasound-assisted in-situ transesterification of soybean oil}

The effects of ultrasound power on fatty acid methyl ester production are shown in Table 5. Increasing the ultrasound power from $70 \%$ to $90 \%$ with methanol to oil volumetric ratio of $25: 1$ increased the FAME yield from $83.9 \%$ to $98.50 \%$. This value indicates that almost all of the oil available in soybeans was converted to biodiesel. Increasing the ultrasound power increased the biodiesel conversion rates. When $70 \%$ ultrasound power was applied, the amount of linoleate acid (C18:2) in the total fatty acid composition was $49.88 \%$. This value increased to $56.83 \%$ with $90 \%$ of ultrasound power. Georgogianni et al. (2008) reported that 
increasing the ultrasound power reduced the time of reaction and increased the biodiesel yield during in-situ transesterification of vegetable oil.

\begin{tabular}{lcccc}
\hline \multicolumn{2}{c}{ Methyl ester } & $\begin{array}{c}\text { Ultrasound } \\
\text { power }(90 \%)\end{array}$ & $\begin{array}{c}\text { Ultrasound power } \\
(70 \%)\end{array}$ & $\begin{array}{c}\text { GV Vegetable oil } \\
\text { reference }\end{array}$ \\
\hline Palmitate & $(\mathrm{C} 16: 0)$ & 10.12 & 9.84 & 10.0 \\
Stearate & $(\mathrm{C} 18: 0)$ & 3.36 & 2.89 & 4.68 \\
Oleate & $(\mathrm{C} 18: 1)$ & 17.46 & 10.55 & 21.8 \\
Linoleate & $(\mathrm{C} 18: 2)$ & 56.83 & 49.88 & 58.3 \\
Linolenate & $(\mathrm{C} 18: 3)$ & 10.26 & 9.91 & 7.49 \\
Arachinate & $(\mathrm{C} 20: 0)$ & 0.45 & $\mathrm{ND}$ & $\mathrm{ND}$ \\
\hline Total & & 88.50 & 83.09 & 102 \\
\hline SD= 10.32 & & & \\
\hline
\end{tabular}

Table 5. Fatty acid composition of biodiesel produced using ultrasound-assisted in-situ transesterification at methanol to oil volumetric ratio of 25:1 (ND: Not detected).

The effect of ultrasound power on FAME yield at different methanol to oil ratio are shown in Fig. 8. In general, increasing the methanol to oil volumetric ratio, increased the biodiesel yield (Haas et al., 2004). Also, increasing ultrasound power from $70 \%$ to $90 \%$ at different methanol levels showed significant effect on oil yield. At low ultrasound power levels, increasing the methanol to oil ratio from 15:1 to 25:1 increased the biodiesel yield from 80.96 $\%$ to $83.09 \%$. While at the same methanol to oil ratio, at high ultrasound power level, biodiesel yield increased from $85.92 \%$ to $98.50 \%$. Catalyst concentration was kept constant for all trials. The statistical coefficient of determination showed a value of $\mathrm{R}^{2}=0.96$ with high ultrasound power level, while $\mathrm{R}^{2}=0.64$ with low ultrasound power level.

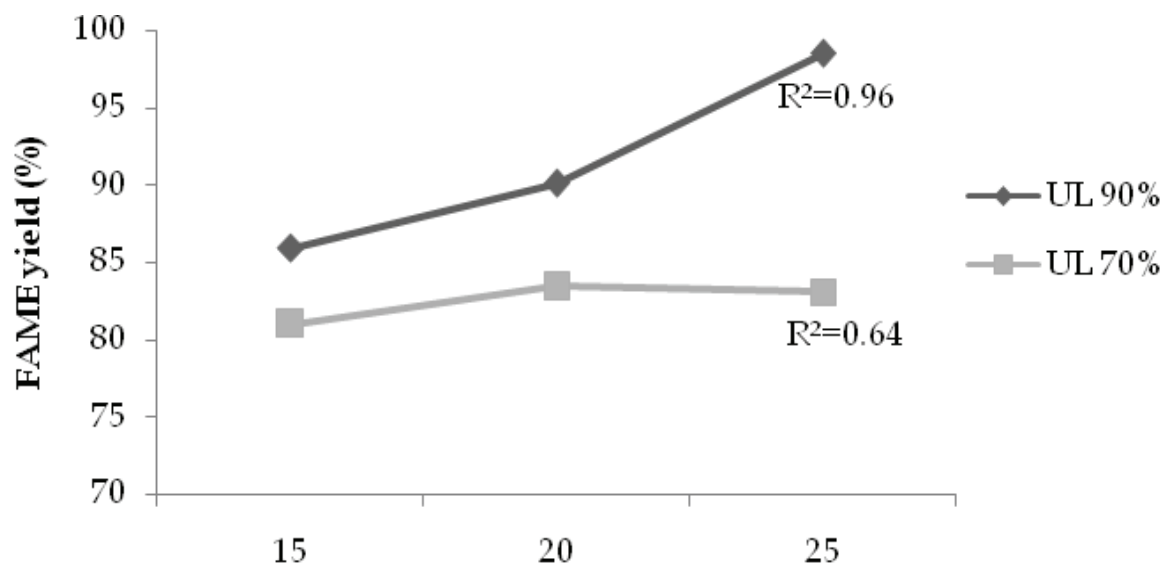

Methnol to oil ratio(v/v)

Fig. 8. Ultrasound effect on FAME yield at different methanol to oil ratio.

This value indicated that ultrasound power has high impact during in-situ transesterification of soybean oil with increasing methanol to oil ratio. Similar results were also reported by Qian et al. (2008). The effect of ultrasound power on various methanol to 
oil ratio on oil to biodiesel conversion rate is shown in Fig. 9. The figure shows that increasing ultrasound power increased the oil yield. The coefficient of determination factor had a value of $R^{2}=0.89$ with high ultrasound power, whereas low power obtained $R^{2}=0.25$. These results confirmed the lower ability of methanol on oil extraction without ultrasonication effect in comparison with other solvents or alcoholic mixtures. Similar results were reported on methanol effect during biodiesel production by (Kim et al., 2010; Qian et al., 2008).

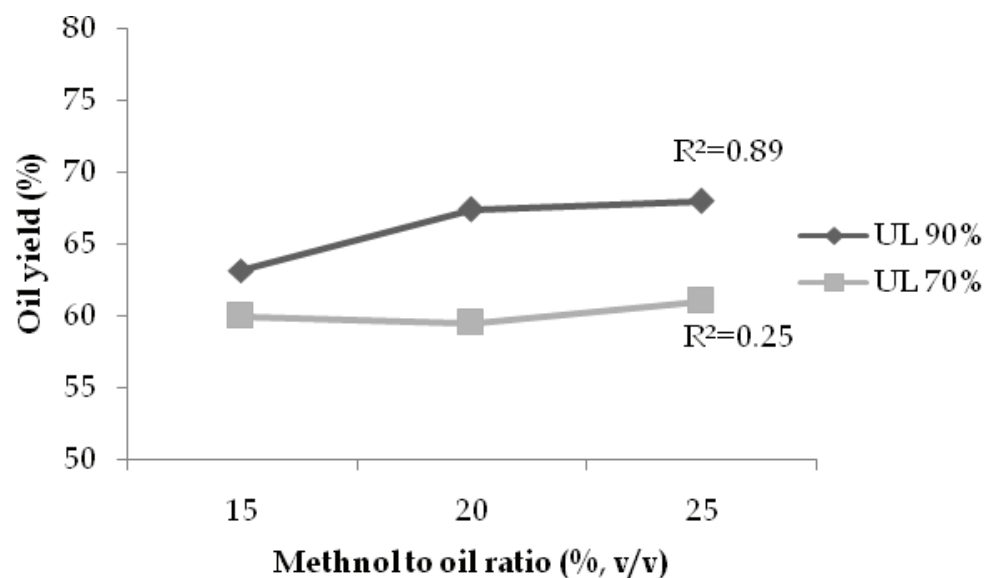

Fig. 9. Ultrasound effect on oil yield at different methanol to oil ratio.

\section{Conclusions}

In this study, oil extraction from soybeans and biodiesel production was performed using conventional and ultrasonication methods. The effects of ultrasonication, solvent to solid ratio and particle size on oil extraction from soybeans were investigated using response surfaces methodology. The results showed that ultrasound did not have a significant effect on oil extraction from soybean flakes, but particle size and hexane amount to solid ratio showed a significant effect on oil yield. Biodiesel production was performed by using ultrasound-assisted transesterification and in-situ transesterification methods. The results of in-situ transesterification showed that ultrasonication had a highly significant effect on biodiesel yield. The qualities of final biodiesel products were analyzed and the results showed that the physical properties of biodiesel produced with mechanical stirring and ultrasonication were within the ASTM standard ranges. Ultrasound power is an effective tool on in-situ transesterification during biodiesel production from soybeans. The future studies will include developing continuous in-situ transesterification systems that uses high intensity ultrasound for in-situ transesterification of soybean oil.

\section{References}

Abreu, F., Lima, D., Hamú, E., Einloft, S., Rubim, J., Suarez, P. 2003. New metal catalysts for soybean oil transesterification. Journal of the American Oil Chemists' Society, 80(6), 601-604. 
Chand, P., Chintareddy, V.R., Verkade, J.G., Grewell, D. 2010. Enhancing Biodiesel Production from Soybean Oil Using Ultrasonics. Energy \& Fuels, 24(3), 2010-2015.

Cintas, P., Mantegna, S., Gaudino, E.C., Cravotto, G. 2010. A new pilot flow reactor for highintensity ultrasound irradiation. Application to the synthesis of biodiesel. Ultrasonics Sonochemistry, 17(6), 985-989.

Cravotto, G., Boffa, L., Mantegna, S., Perego, P., Avogadro, M., Cintas, P. 2008. Improved extraction of vegetable oils under high-intensity ultrasound and/or microwaves. Ultrasonics Sonochemistry, 15(5), 898-902.

Ehimen, E.A., Sun, Z.F., Carrington, C.G. 2010. Variables affecting the in situ transesterification of microalgae lipids. Fuel, 89(3), 677-684.

FAO. 2009. THE STATE OF FOOD AND AGRICULTURE 2009, FAO. Rome, Italy.

Fereidouni, M., Daneshi, A., Younesi, H. 2009. Biosorption equilibria of binary Cd(II) and $\mathrm{Ni}(\mathrm{II})$ systems onto Saccharomyces cerevisiae and Ralstonia eutropha cells: Application of response surface methodology. Journal of Hazardous Materials, 168(23), 1437-1448.

Fukuda, H., Kondo, A., Noda, H. 2001. Biodiesel fuel production by transesterification of oils. Journal of Bioscience and Bioengineering, 92(5), 405-416.

Gandhi, A.P., Joshi, K.C., Jha, K., Parihar, V.S., Srivastav, D.C., Raghunadh, P., Kawalkar, J., Jain, S.K., Tripathi, R.N. 2003. Studies on alternative solvents for the extraction of oil-I soybean. International Journal of Food Science \& Technology, 38(3), 369-375.

Georgogianni, K.G., Kontominas, M.G., Pomonis, P.J., Avlonitis, D., Gergis, V. 2008. Conventional and in situ transesterification of sunflower seed oil for the production of biodiesel. Fuel Processing Technology, 89(5), 503-509.

Gerpen, J.V., B. Shanks, R. Pruszko, D. Clements, Knothe, G. 2002. Biodiesel Production Techonlogy, National Renewable Energy Laboratory.

Haas, M., Scott, K., Marmer, W., Foglia, T. 2004. \&lt;i\&gt;In situ\&lt;/i\&gt; alkaline transesterification: An effective method for the production of fatty acid esters from vegetable oils. Journal of the American Oil Chemists' Society, 81(1), 83-89.

Han, X., Cheng, L., Zhang, R., Bi, J. 2009. Extraction of safflower seed oil by supercritical CO2. Journal of Food Engineering, 92(4), 370-376.

Harrington, K., D'Arcy-Evans, C. 1985. A comparison of conventional and in situ methods of transesterification of seed oil from a series of sunflower cultivars. Journal of the American Oil Chemists' Society, 62(6), 1009-1013.

Jung, S., Mahfuz, A.A., 2009. Low temperature dry extrusion and high-pressure processing prior to enzyme-assisted aqueous extraction of full fat soybean flakes. Food Chemistry 114, 947-954.

Kao, T.-H., Chien, J.-T., Chen, B.-H. 2008. Extraction yield of isoflavones from soybean cake as affected by solvent and supercritical carbon dioxide. Food Chemistry, 107(4), 17281736.

Kargbo, D.M. 2010. Biodiesel Production from Municipal Sewage Sludges. Energy Fuels, 24 (5), 2791-2794.

Kashyap, M.C., Agrawal, Y.C., Ghosh, P.K., Jayas, D.S., Sarkar, B.C., Singh, B.P.N. 2007. Oil extraction rates of enzymatically hydrolyzed soybeans. Journal of Food Engineering, 81(3), 611-617. 
Kim, M., Yan, S., Salley, S.O., Ng, K.Y.S. 2010. Competitive transesterification of soybean oil with mixed methanol/ethanol over heterogeneous catalysts. Bioresource Technology, 101(12), 4409-4414.

Koc, A.B., McKenzie, E.H. 2010. Effects of ultrasonication on glycerin separation during transesterification of soybean oil. Fuel Processing Technology, 91(7), 743-748.

Leung, D.Y.C., Wu, X., Leung, M.K.H. 2010. A review on biodiesel production using catalyzed transesterification. Applied Energy, 87(4), 1083-1095.

Li, H., Pordesimo, L., Weiss, J. 2004. High intensity ultrasound-assisted extraction of oil from soybeans. Food Research International, 37(7), 731-738.

Lim, S., Hoong, S.S., Teong, L.K., Bhatia, S. 2010. Supercritical fluid reactive extraction of Jatropha curcas L. seeds with methanol: A novel biodiesel production method. Bioresource Technology, 101(18), 7169-7172.

Lotero, E., Liu, Y., Lopez, D.E., Suwannakarn, K., Bruce, D.A., Goodwin, J.G. 2005. Synthesis of Biodiesel via Acid Catalysis. Industrial \& Engineering Chemistry Research, 44(14), 5353-5363.

Lou, Z., Wang, H., Zhang, M., Wang, Z. 2010. Improved extraction of oil from chickpea under ultrasound in a dynamic system. Journal of Food Engineering, 98(1), 13-18.

Luthria, D.L., Biswas, R., Natarajan, S. 2007. Comparison of extraction solvents and techniques used for the assay of isoflavones from soybean. Food Chemistry, 105(1), 325-333.

Ma, F., Hanna, M.A. 1999. Biodiesel production: a review. Bioresource Technology, 70(1), 1-15.

Marchetti, J.M., Errazu, A.F. 2008. Esterification of free fatty acids using sulfuric acid as catalyst in the presence of triglycerides. Biomass and Bioenergy, 32(9), 892-895.

Meher, L.C., Vidya Sagar, D., Naik, S.N. 2006. Technical aspects of biodiesel production by transesterification--a review. Renewable and Sustainable Energy Reviews, 10(3), 248268.

Mendes, M.F., Pessoa, F.L.P., Uller, A.M.C. 2002. An economic evaluation based on an experimental study of the vitamin E concentration present in deodorizer distillate of soybean oil using supercritical CO2. The Journal of Supercritical Fluids, 23(3), 257265.

Mielenz, J.R., Bardsley, J.S., Wyman, C.E. 2009. Fermentation of soybean hulls to ethanol while preserving protein value. Bioresource Technology, 100(14), 3532-3539.

Nur 'Aliaa, A., Siti Mazlina, M., Taip, F., Liew Abdullah, A. 2010. RESPONSE SURFACE OPTIMIZATION FOR CLARIFICATION OF WHITE PITAYA JUICE USING A COMMERCIAL ENZYME. Journal of Food Process Engineering, 33(2), 333-347.

Pagliero, C., Mattea, M., Ochoa, N., Marchese, J. 2007. Fouling of polymeric membranes during degumming of crude sunflower and soybean oil. Journal of Food Engineering, 78(1), 194-197.

Patil, P.D., Deng, S. 2009. Optimization of biodiesel production from edible and non-edible vegetable oils. Fuel, 88(7), 1302-1306.

Pereira, R.G., Oliveira, C.D., Oliveira, J.L., Oliveira, P.C.P., Fellows, C.E., Piamba, O.E. 2007. Exhaust emissions and electric energy generation in a stationary engine using blends of diesel and soybean biodiesel. Renewable Energy, 32(14), 2453-2460.

Pinto, A.C., Guarieiro, L.L.N., Rezende, M.J.C., Ribeiro, N.M., Torres, E.A., Lopes, W.A., De Pereira, P.A.P., De Andrade, J.B. 2005. Biodiesel: An overview. Journal of the Brazilian Chemical Society, 16(6 B), 1313-1330. 
Qi, D.H., Geng, L.M., Chen, H., Bian, Y.Z., Liu, J., Ren, X.C. 2009. Combustion and performance evaluation of a diesel engine fueled with biodiesel produced from soybean crude oil. Renewable Energy, 34(12), 2706-2713.

Qian, J., Wang, F., Liu, S., Yun, Z. 2008. In situ alkaline transesterification of cottonseed oil for production of biodiesel and nontoxic cottonseed meal. Bioresource Technology, 99(18), 9009-9012.

Ribeiro, A.P.B., Bei, N., Guaraldo Gonçalves, L.A., Cunha Petrus, J.C., Viotto, L.A. 2008. The optimisation of soybean oil degumming on a pilot plant scale using a ceramic membrane. Journal of Food Engineering, 87(4), 514-521.

Russin, T., Boye, J., Arcand, Y., Rajamohamed, S. 2010. Alternative Techniques for Defatting Soy: A Practical Review. Food and Bioprocess Technology.

SalgIn, U. 2007. Extraction of jojoba seed oil using supercritical CO2+ethanol mixture in green and high-tech separation process. The Journal of Supercritical Fluids, 39(3), 330337.

Santos, F.F.P., Rodrigues, S., Fernandes, F.A.N. 2009. Optimization of the production of biodiesel from soybean oil by ultrasound assisted methanolysis. Fuel Processing Technology, 90(2), 312-316.

Sanz Requena, J.F., Guimaraes, A.C., Quirós Alpera, S., Relea Gangas, E., HernandezNavarro, S., Navas Gracia, L.M., Martin-Gil, J., Fresneda Cuesta, H. 2010. Life Cycle Assessment (LCA) of the biofuel production process from sunflower oil, rapeseed oil and soybean oil. Fuel Processing Technology, In Press, Corrected Proof.

Seth, S., Agrawal, Y.C., Ghosh, P.K., Jayas, D.S., Singh, B.P.N. 2007. Oil extraction rates of soya bean using isopropyl alcohol as solvent. Biosystems Engineering, 97(2), 209-217.

Shiu, P.-J., Gunawan, S., Hsieh, W.-H., Kasim, N.S., Ju, Y.-H. 2010. Biodiesel production from rice bran by a two-step in-situ process.

Sin, H.N., Yusof, S., Abdul Hamid, N.S., Abd. Rahman, R. 2006. Optimization of hot water extraction for sapodilla juice using response surface methodology. Journal of Food Engineering, 74(3), 352-358.

Singh, J., Bargale, P.C. 2000. Development of a small capacity double stage compression screw press for oil expression. Journal of Food Engineering, 43(2), 75-82.

Singh, S.P., Singh, D. 2010. Biodiesel production through the use of different sources and characterization of oils and their esters as the substitute of diesel: A review. Renewable and Sustainable Energy Reviews, 14(1), 200-216.

Stavarache, C., Vinatoru, M., Nishimura, R., Maeda, Y. 2005. Fatty acids methyl esters from vegetable oil by means of ultrasonic energy. Ultrasonics Sonochemistry, 12(5), 367372 .

Terigar, B.G., Balasubramanian, S., Boldor, D., Xu, Z., Lima, M., Sabliov, C.M. 2010. Continuous microwave-assisted isoflavone extraction system: Design and performance evaluation. Bioresource Technology, 101(7), 2466-2471.

United States Department of Agriculture, N.A.S.S. 2008. 2008 Agricultural Statistics Annual, United States Department of Agriculture, National Agriculture Statistic Service.

Uquiche, E., Jeréz, M., Ortíz, J. 2008. Effect of pretreatment with microwaves on mechanical extraction yield and quality of vegetable oil from Chilean hazelnuts (Gevuina avellana Mol). Innovative Food Science \& Emerging Technologies, 9(4), 495-500.

Verziu, M., Florea, M., Simon, S., Simon, V., Filip, P., Parvulescu, V.I., Hardacre, C. 2009. Transesterification of vegetable oils on basic large mesoporous alumina supported 
alkaline fluorides--Evidences of the nature of the active site and catalytic performances. Journal of Catalysis, 263(1), 56-66.

Yu, D., Tian, L., Wu, H., Wang, S., Wang, Y., Ma, D., Fang, X. 2010. Ultrasonic irradiation with vibration for biodiesel production from soybean oil by Novozym 435 . Process Biochemistry, 45(4), 519-525.

Zaidul, I.S.M., Nik Norulaini, N.A., Mohd Omar, A.K., Smith, J.R.L. 2007. Supercritical carbon dioxide (SC-CO2) extraction of palm kernel oil from palm kernel. Journal of Food Engineering, 79(3), 1007-1014.

Zhang, Z.-S., Wang, L.-J., Li, D., Jiao, S.-S., Chen, X.D., Mao, Z.-H. 2008. Ultrasound-assisted extraction of oil from flaxseed. Separation and Purification Technology, 62(1), 192-198. 


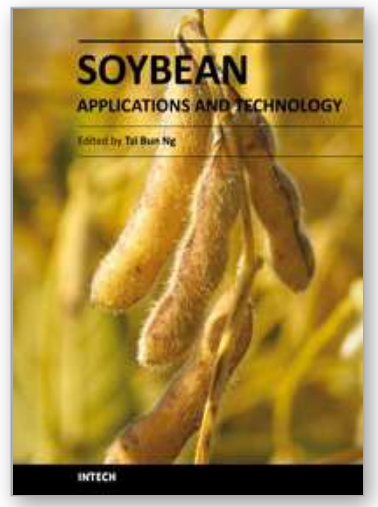

\section{Soybean - Applications and Technology \\ Edited by Prof. Tzi-Bun Ng}

ISBN 978-953-307-207-4

Hard cover, 402 pages

Publisher InTech

Published online 26, April, 2011

Published in print edition April, 2011

Soybean is an agricultural crop of tremendous economic importance. Soybean and food items derived from it form dietary components of numerous people, especially those living in the Orient. The health benefits of soybean have attracted the attention of nutritionists as well as common people.

\section{How to reference}

In order to correctly reference this scholarly work, feel free to copy and paste the following:

A. Bulent Koc, Mudhafer Abdullah and Mohammad Fereidouni (2011). Soybeans Processing for Biodiesel Production, Soybean - Applications and Technology, Prof. Tzi-Bun Ng (Ed.), ISBN: 978-953-307-207-4, InTech, Available from: http://www.intechopen.com/books/soybean-applications-and-technology/soybeansprocessing-for-biodiesel-production

\section{INTECH}

open science | open minds

\section{InTech Europe}

University Campus STeP Ri

Slavka Krautzeka 83/A

51000 Rijeka, Croatia

Phone: +385 (51) 770447

Fax: +385 (51) 686166

www.intechopen.com

\section{InTech China}

Unit 405, Office Block, Hotel Equatorial Shanghai

No.65, Yan An Road (West), Shanghai, 200040, China

中国上海市延安西路65号上海国际贵都大饭店办公楼405单元

Phone: +86-21-62489820

Fax: $+86-21-62489821$ 
(C) 2011 The Author(s). Licensee IntechOpen. This chapter is distributed under the terms of the Creative Commons Attribution-NonCommercialShareAlike-3.0 License, which permits use, distribution and reproduction for non-commercial purposes, provided the original is properly cited and derivative works building on this content are distributed under the same license. 